\title{
September 14 Highlight and Commentary
}

\section{Risk of driving with Alzheimer disease}

In a route finding task on the road using an instrumented vehicle, Uc et al. found that drivers with mild Alzheimer disease (AD) made more navigational and safety errors than neurologically normal older adults. Task performance and driving safety were predicted by scores on standardized tests sensitive to visual and cognitive sensitive decline in early $\mathrm{AD}$.

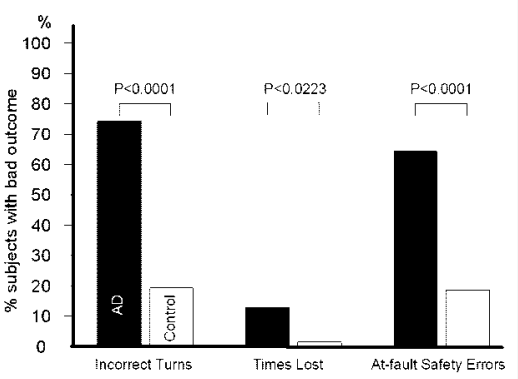

see page 832

\section{Safe driving: Aging and Alzheimer disease}

Commentary by David A. Drachman, MD

Operating a motor vehicle is the most dangerous thing that most people do. On average, in the United States a driver will be involved in a crash once every 10 years-varying with miles driven, use of alcohol, the driver's age, and certain medical conditions. Each state's Motor Vehicle Registry grants the privilege of a license if the driver's level of competence does not unduly endanger him- or herself or others. Two imperfectly resolved safety issues are the age of the driver and the role of $\mathrm{AD}$.

Aging per se does not increase the annual risk of an accident. Drivers over 75 have an accident rate less than $20 \%$ that of 16-yearolds, partly due to restricting the miles driven and limiting night driving. The elderly are more likely to have visual, cognitive, or medical problems, however, and 25 states require vision tests, more frequent or in-person re- newals, or (in three states) road tests.

$\mathrm{AD}$, affecting $10 \%$ of the population over 65 , and almost $50 \%$ of those over 85, eventually results in impaired ability to drive safely. ${ }^{1}$ Competence often declines slowly, and the challenge is to recognize how long the person with $\mathrm{AD}$ can continue to drive safely. Methods of determining driving competence include recent driving record, cognitive screening tests, useful field of view testing, Clinical Dementia Rating assessments, ${ }^{2}$ driving simulator performance, and on-road driving tests.

The study by Uc et al. found that patients with mild $\mathrm{AD}$ performed less well than normal controls on an on-road driving test requiring route following. Some $\mathrm{AD}$ patients performed satisfactorily, however, and few cognitive tests distinguished them from those who performed poorly. AD patients familiar with the streets where they were tested performed better than those unfamiliar with the area.

Assuring reasonably safe driving in patients with early $\mathrm{AD}$ remains difficult. On-road performance, evaluated by an experienced instructor, is currently the best measure of driving competence. If the patient is safe today, I recommend that a family member ride with the patient at least once a month, and if the observer feels endangered, the driver should no longer operate a vehicle.

\section{References}

1. Drachman DA, Swearer JM. Driving and Alzheimer's disease: the risk of crashes. Neurology 1993;43:24482456.

2. Dubinsky RM, Stein AC, Lyons K. Practice parameter: risk of driving and Alzheimer's disease (an evidence-based review). Neurology 2000;54:2205-2211.

See page 832 


\section{Neurology}

\section{September 14 Highlight and Commentary \\ Neurology 2004;63;765 \\ DOI 10.1212/WNL.63.5.765}

This information is current as of September 13, 2004

\section{Updated Information \&} Services

References

Permissions \& Licensing

Reprints including high resolution figures, can be found at: http://n.neurology.org/content/63/5/765.full

This article cites 2 articles, 2 of which you can access for free at: http://n.neurology.org/content/63/5/765.full\#ref-list-1

Information about reproducing this article in parts (figures,tables) or in its entirety can be found online at:

http://www.neurology.org/about/about_the_journal\#permissions

Information about ordering reprints can be found online:

http://n.neurology.org/subscribers/advertise

Neurology ${ }^{\circledR}$ is the official journal of the American Academy of Neurology. Published continuously since 1951, it is now a weekly with 48 issues per year. Copyright . All rights reserved. Print ISSN: 0028-3878. Online ISSN: 1526-632X.

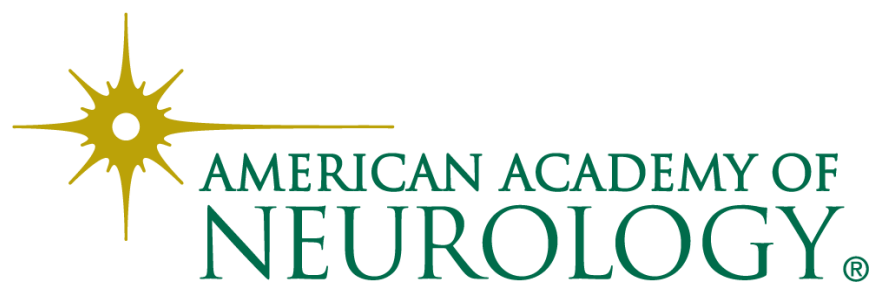

